Copyright (c) 2015 by Academic Publishing House Researcher

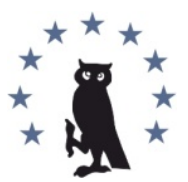

Published in the Russian Federation European J ournal of Medicine. Series B Has been issued since 2014.

ISSN: 2409-6296

Vol. 3, Is. 2, pp. 104-110, 2015

DOI: 10.13187/ ejm.s.b.2015.3.104

www.ejournal27.com

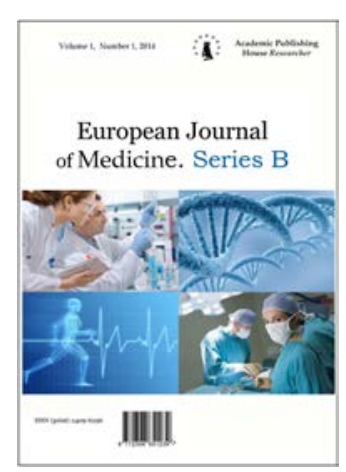

UDC 616.61-008.64- 053.2-001.8

\title{
Toxic Elements Content in Serum and Erythrocytes in Newborns With Disturbance Kidney Function Due to Asphyxia
}

\author{
Andrii Loboda
}

Sumy State University, Sumy, Ukraine

Sanatorna Str., 31, Sumy, Ukraine, 40018

$\mathrm{PhD}$, Associate professor

E-mail: fafik1313@rambler.ru

\section{Abstract}

The aim of the investigation is explore the features of the content and balance of toxic electrolytes (aluminum, cadmium and lead) in serum and red blood cells of newborns with disturbance kidney function due to asphyxia.

Investigation included 200 full-term newborns with the signs of renal damage: 100 neonates suffered severe asphyxia, and 100 babies suffered moderate asphyxia. A comparison group comprised 20 infants without asphyxia at birth. Blood was collected on the 1-2 day of life, at the end of the early neonatal period (7- 8 day of life), and at the end of the first month (25- 30 day). The content of electrolytes in blood serum and erythrocytes was determined by atomic absorption spectrophotometry (AAS).

For newborns with impaired renal function were typical high level of $\mathrm{Al}, \mathrm{Cd}, \mathrm{Pb}$ in blood serum during early neonatal period in case of moderate asphyxia or predominantly during whole $1^{\text {st }}$ month of life in case of severe form. Prolonged increase levels of toxic elements in erythrocytes more specific for neonates with disturbance kidney function due to severe asphyxia. Transmembrane ratio of all investigated toxic elements indicated on preferred movement ions inward of the cell.

Keywords: asphyxia, newborn, toxic microelement, serum, erythrocyte.

\section{Introduction}

Asphyxia promotes the development of multiple organ dysfunctions. The most exposed target -organs in this case are kidneys, frequency of which involvement varies from 47,1\% to $70 \%[1,2]$. Renal dysfunction can be formed on the first day of life on the background of tissue hypoxia due to metabolic disorders, hemodynamic disturbance and violation of microcirculation [1]. However, kidneys are also main ways of elimination of trace elements, including toxic, from the human body. Non-essential metals such as aluminum (Al), cadmium $(\mathrm{Cd})$ and lead $(\mathrm{Pb})$ are ubiquitous persistent environmental toxicants known to bioaccumulate in the human body. All these metals are highly toxic even in trace amounts [3], and the global burden of $\mathrm{Al}, \mathrm{Cd}$ and $\mathrm{Pb}$ remains high due to their widespread usage in industrial and manufacturing processes. Exposure occurs primarily through the ingestion of pregnant woman contaminated food and drinking water, the inhalation of contaminated air, and smoking with secondary negative influence on fetus [3, 4]. The placenta can take up some of the toxic ions very actively and than transmitted them to fetus [5]. 
The aim of the investigation is explore the features of the content and balance of toxic electrolytes (aluminum, cadmium and lead) in serum and red blood cells of newborns with disturbance kidney function due to asphyxia.

\section{Materials and methods}

Investigation included 200 full-term newborns with the signs of renal damage. Infants were divided into two groups: group $1(n=100)$ - neonates suffered severe asphyxia, group 2 $(\mathrm{n}=100)$ - babies suffered moderate asphyxia. A comparison group comprised 20 infants without asphyxia at birth.

The study complies with the Declaration of Helsinki (the Declaration was passed in Helsinki, Finland, June, 1964, and revised in October, 2000, Edinburg, Scotland) and was performed following approval by the Ethic Committee of Sumy State University. Written informed consent was obtained from the parents of the newborns.

Kidney dysfunction was diagnosed, if the level of blood creatinine was higher than 89 $\mu \mathrm{mol} / \mathrm{L}$, blood urea - higher than $8 \mathrm{mmol} / \mathrm{L}$, urine output dropped lower than $1 \mathrm{ml} / \mathrm{kg} / \mathrm{h}$ [6]. The diagnosis of moderate and severe asphyxia was established according to the "Initial newborn resuscitation and post-resuscitation aid in Ukraine" (Order of the Ministry of Health of Ukraine, 28.03.2014, No.225).

Blood was collected on the 1- 2 day of life, at the end of the early neonatal period (7- 8 day of life), and at the end of the first month (25- 30 day).

Fasting venous blood samples were obtained for analysis in the morning from all children into sterile tubes with EDTA. After two hours, standing and centrifugation at $3500 \mathrm{rpm}$ for 10 minutes, blood serum and erythrocytes were separated. The red blood cells were washed twice. The samples of the blood serum and erythrocytes were put in closed plastic laboratory vessels and stored at $-18^{\circ} \mathrm{C}$ until trace element analysis.

The content of electrolytes in blood serum and erythrocytes was determined by atomic absorption spectrophotometry (AAS) on a spectrophotometer C-115 M1 (J SC "Selmi," Ukraine), also expected toxic elements transmembrane ratio.

Statistical data processing was performed using Excel (Microsoft Corporation, Redmond, WA), and Statistica 6.1 (StatSoft, USA). All values were expressed as mean (M) \pm mean deviation (m). Wilcoxon's test was used to evaluate differences between study groups. Statistically significant differences were indicated by p values $<0,05$.

\section{Results}

The level of aluminum was in physiological range in all groups of newborns during neonatal period (tab. 1). This level in neonates of comparison group was constant but had tendency to increase. At the same time in newborns with disturbance kidney function due to severe asphyxia serum aluminum was statistically higher relative to healthy children during the entire period. Maximal aluminum level was typical on the 7-8 $8^{\text {th }}$ day of life. In the patients with disturbance kidney function due to moderate asphyxia serum aluminum was statistically higher relative to comparison group only during early neonatal period. At the end of $1^{\text {st }}$ month of life its level not differs from healthy children. The serum content of aluminum was independent of the severity of asphyxia.

Thus, children with renal impairment due to asphyxia have elevated serum aluminum level, which normalized only in case of moderate asphyxia at the end of neonatal period.

Table 1: Serum content of toxic microelements, pmole/l

\begin{tabular}{|c|c|c|c|c|c|c|c|c|c|}
\hline \multirow{3}{*}{$\mathrm{Al}$} & \multicolumn{9}{|c|}{ Newborns } \\
\hline & \multicolumn{3}{|c|}{$\begin{array}{c}\text { With kidney damage due } \\
\text { to severe } \\
\text { asphyxia }\end{array}$} & \multicolumn{3}{|c|}{$\begin{array}{c}\text { With kidney damage due to } \\
\text { moderate } \\
\text { asphyxia }\end{array}$} & \multicolumn{3}{|c|}{ Comparison group } \\
\hline & 1-2 day & $\begin{array}{l}\text { 7-8 } \\
\text { day }\end{array}$ & $\begin{array}{c}25-30 \\
\text { day }\end{array}$ & $\begin{array}{l}1-2 \\
\text { day }\end{array}$ & 7-8 day & $\begin{array}{c}25-30 \\
\text { day }\end{array}$ & $\begin{array}{l}1-2 \\
\text { day }\end{array}$ & $\begin{array}{l}\text { 7-8 } \\
\text { day }\end{array}$ & $\begin{array}{l}25- \\
30 \\
\text { day }\end{array}$ \\
\hline
\end{tabular}




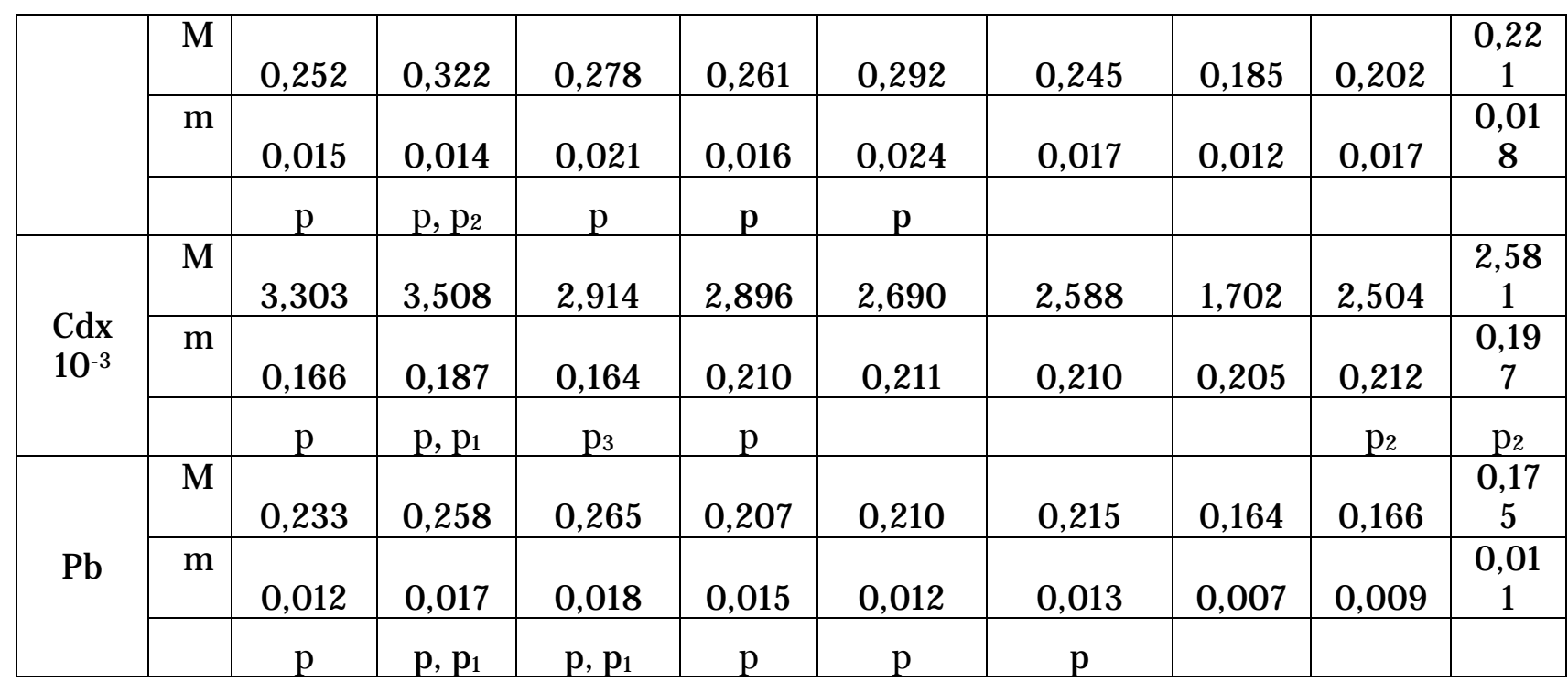

Notes: $\mathrm{p}$ - statistical significance of the value difference relative to the comparison group; $\mathrm{p}_{1}$ - relative to newborns with moderate asphyxia; $\mathrm{p}_{2}$ - relative to $1-2$ days of life; $\mathrm{p}_{3}$ - relative to 7- 8 days of life.

Toxic levels of serum cadmium have not specific as for comparison group as for newborns with disturbance kidney function due to asphyxia during the neonatal period. Its content did not go beyond reference values. But in healthy newborns its level was statistically increased throughout the first month of life. Neonates with impaired renal function due to asphyxia had another dynamics - serum cadmium content decreased to the end of neonatal period. Despite this concentration of serum cadmium was 1,9 and 1,7 times higher $(\mathrm{p}<0,05)$ on the 1-2nd day of life in newborn with kidney damage due to severe and moderate asphyxia relative to healthy children accordingly. Maximal cadmium level was typical for patients with disturbance kidney function due to severe asphyxia at the end of early neonatal period. It was statistically higher not only relative to healthy children but relative neonates with kidney function disturbance due to moderate asphyxia also. Normalization of serum cadmium content occurred on the 7-8th day of life in case of moderate asphyxia, on the 25-30th day of life only in case of severe asphyxia.

Consequently, for newborns with impaired renal function due to asphyxia was typical relative hypercadmiemia, which is stored during the whole early neonatal period in case of severe asphyxia.

The level of lead in serum of blood was in line with some reported concentrations in all groups of the newborn. This level was stable in neonates of all groups during 1st month of life. But in children with disturbance kidney function due to asphyxia serum lead concentration was higher $(p<0,05)$ during the entire period. Also in newborns with kidney damage due to severe asphyxia it was statistically higher after 7-8th day of life relative to neonates with disturbance kidney function due to moderate asphyxia.

So, increased serum lead content was typical for newborns with impaired renal function due to asphyxia during the neonatal period.

Table 2: Content of toxic microelements in red blood cells, $\mu$ mole/l

\begin{tabular}{|c|c|c|c|c|c|c|c|c|c|c|}
\hline & & \multicolumn{9}{|c|}{ Newborns } \\
\hline \multirow{3}{*}{$\mathrm{Al}$} & & \multicolumn{3}{|c|}{$\begin{array}{c}\text { With kidney damage due to } \\
\text { severe } \\
\text { asphyxia }\end{array}$} & \multicolumn{3}{|c|}{$\begin{array}{c}\text { With kidney damage due to } \\
\text { moderate } \\
\text { asphyxia }\end{array}$} & \multicolumn{3}{|c|}{ Comparison group } \\
\hline & & $\begin{array}{l}1-2 \\
\text { day }\end{array}$ & $\begin{array}{l}\text { 7-8 } \\
\text { day }\end{array}$ & $\begin{array}{c}25-30 \\
\text { day }\end{array}$ & 1-2 day & $\begin{array}{l}\text { 7-8 } \\
\text { day }\end{array}$ & $\begin{array}{c}25-30 \\
\text { day }\end{array}$ & $\begin{array}{l}1-2 \\
\text { day }\end{array}$ & 7-8 day & $\begin{array}{l}25- \\
30 \\
\text { day }\end{array}$ \\
\hline & $\mathrm{M}$ & 0,311 & 0,337 & 0,243 & 0,268 & 0,223 & 0,202 & 0,217 & 0,197 & $\begin{array}{c}0,18 \\
1\end{array}$ \\
\hline
\end{tabular}




\begin{tabular}{|c|c|c|c|c|c|c|c|c|c|c|}
\hline & $\mathrm{m}$ & 0,015 & 0,019 & 0,019 & 0,014 & 0,013 & 0,013 & 0,017 & 0,013 & $\begin{array}{c}0,01 \\
3 \\
\end{array}$ \\
\hline & & $\mathrm{p}, \mathrm{p}_{1}$ & $\mathrm{p}, \mathrm{p}_{1}$ & $\mathrm{p}, \mathrm{p}_{2}, \mathrm{p}_{3}$ & p & $\mathrm{p}_{2}$ & $\mathrm{p}_{2}$ & & & \\
\hline \multirow{3}{*}{$\begin{array}{l}C d x \\
10^{-3}\end{array}$} & $\mathrm{M}$ & 5,580 & 4,913 & 4,030 & 5,072 & 4,776 & 3,619 & 2,672 & 2,889 & $\begin{array}{l}3,2 \\
29\end{array}$ \\
\hline & $\mathrm{m}$ & 0,269 & 0,271 & 0,226 & 0,272 & 0,286 & 0,174 & 0,199 & 0,216 & $\begin{array}{c}0,14 \\
8\end{array}$ \\
\hline & & $p$ & $p$ & $\mathrm{p}_{2}, \mathrm{p}_{3}$ & p & $p$ & $\mathrm{p}_{2}, \mathrm{p}_{3}$ & & & $\mathrm{p}_{2}$ \\
\hline \multirow{3}{*}{$\mathrm{Pb}$} & $\mathrm{M}$ & 0,673 & 0,768 & 0,790 & 0,621 & 0,636 & 0,648 & 0,497 & 0,531 & $\begin{array}{l}0,5 \\
24\end{array}$ \\
\hline & $\mathrm{m}$ & 0,029 & 0,035 & 0,042 & 0,041 & 0,045 & 0,034 & 0,018 & 0,019 & $\begin{array}{c}0,01 \\
7\end{array}$ \\
\hline & & $p$ & $\mathrm{p}, \mathrm{p}_{1}, \mathrm{p}_{2}$ & $\mathrm{p}, \mathrm{p}_{1}, \mathrm{p}_{2}$ & $\mathrm{p}$ & & $p$ & & & \\
\hline
\end{tabular}

Notes: $\mathrm{p}$ - statistical significance of the value difference relative to the comparison group; $\mathrm{p}_{1}$ - relative to newborns with moderate asphyxia; $\mathrm{p}_{2}$ - relative to 1- 2 days of life; $\mathrm{p}_{3}$ - relative to 7- 8 days of life.

The content of electrolytes in erythrocytes of surveyed children also had certain peculiarities (tab. 2). Intracellular aluminum content was elevated on the 1-2 ${ }^{\text {nd }}$ day of life in all newborns with disturbance kidney function due to asphyxia. But in neonates who suffered severe asphyxia its level was statistically higher. Highest aluminum concentration in this group was found on the 7-8 $8^{\text {th }}$ day of life. Later content of the microelement decreased on $27,9 \%(\mathrm{p}<0,05)$ but remained still higher relative to healthy children. Aluminum content in erythrocytes normalized at the end of early neonatal period in newborns with kidney damage due to moderate asphyxia.

Table 3: Transmembrane ratio of electrolytes

\begin{tabular}{|c|c|c|c|c|c|c|c|c|c|}
\hline & \multicolumn{9}{|c|}{ Newborns } \\
\hline & \multicolumn{3}{|c|}{$\begin{array}{c}\text { With kidney damage due to } \\
\text { severe } \\
\text { asphyxia }\end{array}$} & \multicolumn{3}{|c|}{$\begin{array}{l}\text { With kidney damage due to } \\
\text { moderate } \\
\text { asphyxia }\end{array}$} & \multicolumn{3}{|c|}{ Comparison group } \\
\hline & 1-2 day & $\begin{array}{l}\text { 7-8 } \\
\text { day }\end{array}$ & $\begin{array}{c}25-30 \\
\text { day }\end{array}$ & 1-2 day & $\begin{array}{l}\text { 7-8 } \\
\text { day }\end{array}$ & $\begin{array}{c}25-30 \\
\text { day }\end{array}$ & 1-2 day & $\begin{array}{l}7-8 \\
\text { day }\end{array}$ & $\begin{array}{c}25-30 \\
\text { day }\end{array}$ \\
\hline $\mathrm{Al}_{\mathrm{er}} / \mathrm{Al}_{\mathrm{s}}$ & $\begin{array}{l}1,413 \pm \\
0,104 \\
p\end{array}$ & $\begin{array}{l}1,020 \pm \\
0,069 \\
p_{2}\end{array}$ & $\begin{array}{c}1,061 \pm \\
0,061 \\
p_{1}\end{array}$ & $\begin{array}{l}1,333 \pm \\
0,094 \\
p\end{array}$ & $\begin{array}{l}0,888 \\
\pm 0,117 \\
p_{2}\end{array}$ & $\begin{array}{l}0,869 \pm \\
0,049 \\
p_{2}\end{array}$ & $\begin{array}{l}1,125 \pm \\
0,099\end{array}$ & $\begin{array}{c}1,148 \pm \\
0,150\end{array}$ & $\begin{array}{r}0,940 \\
0,112\end{array}$ \\
\hline $\mathrm{Cd}_{\mathrm{er}} / \mathrm{Cd}_{\mathrm{s}}$ & $\begin{array}{c}1,826 \pm \\
0,088\end{array}$ & $\begin{array}{c}1,859 \pm \\
0,081 \\
p\end{array}$ & $\begin{array}{c}1,563 \pm \\
0,143\end{array}$ & $\begin{array}{c}1,763 \pm \\
0,125\end{array}$ & $\begin{array}{c}1,484 \pm \\
0,109\end{array}$ & $\begin{array}{c}1,448 \pm \\
0,096 \\
\mathrm{p}_{2}\end{array}$ & $\begin{array}{c}1,764 \pm \\
0,131\end{array}$ & $\begin{array}{c}1,399 \pm \\
0,205\end{array}$ & $\begin{array}{c}1,407 \\
\pm \\
0,125 \\
\mathrm{p}_{2}\end{array}$ \\
\hline $\mathrm{Pb}_{\mathrm{er}} / \mathrm{Pb}_{\mathrm{s}}$ & $\begin{array}{c}3,209 \\
\pm \\
0,232\end{array}$ & $\begin{array}{c}3,102 \pm \\
0,268\end{array}$ & $\begin{array}{c}3,043 \pm \\
0,212\end{array}$ & $\begin{array}{c}3,376 \pm \\
0,359\end{array}$ & $\begin{array}{c}3,190 \pm \\
0,281\end{array}$ & $\begin{array}{c}3,185 \pm \\
0,215\end{array}$ & $\begin{array}{c}3,149 \pm \\
0,185\end{array}$ & $\begin{array}{c}3,249 \pm \\
0,248\end{array}$ & $\begin{array}{l}3,371 \\
\pm \\
0,199\end{array}$ \\
\hline
\end{tabular}

Notes: $\mathrm{p}$ - statistical significance of the value difference relative to the comparison group; $\mathrm{p}_{1}$ - relative to newborns with moderate asphyxia; $\mathrm{p}_{2}$ - relative to 1- 2 days of life; $\mathrm{p}_{3}$ - relative to 7- 8 days of life.

Cadmium level in erythrocytes of healthy newborns increased to the end of $1^{\text {st }}$ month of life $(p<0,05)$. Both groups of neonates with impaired renal function due to asphyxia demonstrated statistically high cadmium concentration in red blood cells during early neonatal period and decrease its content $(\mathrm{p}<0,05)$ to the end of neonatal period.

Erythrocyte content of lead in comparison group was constant during neonatal period. Newborns with kidney damage due to moderate asphyxia demonstrated on $25 \%(\mathrm{p}<0,05)$ higher level of lead in red blood cells on 1-2 $2^{\text {nd }}$ day of life relative to healthy children. This level was stable 
during the remaining part of the survey period. Maximal concentrations of lead in erythrocytes during 1st month of life were typical for newborns with kidney damage due to severe asphyxia. Unlike previous group the microelement content increased to the end of neonatal period on $17 \%$ $(\mathrm{p}<0,05)$ and was highest among all investigated children.

Thus, newborns with kidney damage due to asphyxia characterized by increased levels of toxic elements $(\mathrm{Al}, \mathrm{Cd}, \mathrm{Pb})$ in erythrocytes during early neonatal period in case of moderate asphyxia, and during whole 1st month of life in case of severe asphyxia.

Research transmembrane potential of toxic elements (tab. 3, 4) allowed evaluating preferred movement ions inward or outward of the cell.

For transmembrane ratio of aluminum was typical increasing after birth with fast normalization to the end of early neonatal period. Erythrocyte - serum coefficient for cadmium was elevated during first week of life, particular in neonates with impaired kidney function due to severe asphyxia. A high ratio reflects the increase in erythrocyte pool of aluminum and cadmium in neonates with nephropathy due to asphyxia.

Table 4: Graphical representation of toxic elements balance in serum and erythrocytes in neonates with impaired renal function due to asphyxia

\begin{tabular}{|c|c|c|c|}
\hline & Serum & The direction of movement & Erythrocytes \\
\hline $\mathrm{Al}$ & $\uparrow$ & $\rightarrow$ & $\uparrow$ \\
\hline $\mathrm{Cd}$ & $\uparrow$ & $\rightarrow$ & $\uparrow$ \\
\hline $\mathrm{Pb}$ & $\uparrow$ & $\rightarrow$ & $\uparrow$ \\
\hline
\end{tabular}

Transmembrane potential of lead in newborns with renal impairment due to asphyxia on $1-2^{\text {nd }}$ day of life was inherent relative growth, reflecting the tendency to move into the cell. But to the end of neonatal period this trend reversed.

\section{Discussion}

The main source for raising the level of heavy metals in the tissues of newborn is transfer through the placenta to the fetus during pregnancy [5, 7]. High levels of cadmium and lead in the serum and urine of investigated newborns may be due to dietary habits of their mothers, in particular the use of seafood [3, 4, 8]. Smoking (include passive) positively correlate with elevated cadmium and lead levels in neonates $[4,9]$. However, metals may be discarded to the fetus as a detoxification method [10].

For all newborns with disturbance kidney function due to asphyxia are typical increasing serum levels of toxic elements. Their binding to plasma proteins is less, because of the lower concentrations of albumin found in the plasma of newborns. This, however, may not result in faster elimination, because of the immaturity of the kidneys. Also toxic elements $(\mathrm{Al}, \mathrm{Cd}, \mathrm{Pb})$ can primarily deposited in the kidneys [11], with their secondary dysfunction. For example, significant tissue deposition of cadmium provoke negative renal effects include tubular nephropathy manifested by proteinuria, aminoaciduria, glucosuria, phosphaturia, and calcium wastage [12].

The renal function in newborns is tailored for their special needs, thus they have higher retention of minerals than adults and older children. Glomerular filtration at birth is only 30-40\% of that found in adults and tubular secretion and reabsorption are also less efficient [13]. Our investigation shows that the presence of unbound toxic elements in serum of blood may enhance their retention in tissues, at a faster rate because of rapid growth that is indicated by direction of movement toxic elements (table 4). So, the presence of toxic elements in serum and peripheral tissues may worsen course of ischemic nephropathy in newborns.

Increased blood levels of $\mathrm{Al}, \mathrm{Cd}$ and $\mathrm{Pb}$ may associate with oxidative DNA damage in neonates [14]. Cadmium also can induce oxidative damage in erythrocytes causes loss of membrane function by enhancing lipid peroxidation and altering the erythrocyte antioxidant system [15]. About 90\% of blood lead is associated with a red blood cell [16], that's why it together with cadmium may cause strengthening of erythrocytes' degradation, reduce capacity of the blood to carry oxygen and worsen the symptoms of organs dysfunction due to asphyxia. 
The accumulation of toxic metals in the tissues, especially in the brain by metal flux across the blood-brain barrier [17], may adversely affect CNS function in newborns with asphyxia. Tissue aluminum uptake realized through transferrin-receptor mediated endocytosis and an organic anion transporter. Lead uptake may involve a non-energy-dependent process, store-operated calcium channels, and/or an ATP-dependent calcium pump [17]. Cadmium ions have a high affinity for tissue thiols, induce the synthesis of a carrier cysteine-rich polypeptide called metallothionein, and impair proteoglycan metabolism [15].

Levels of toxic ions in serum of blood and erythrocytes in neonates with impaired kidney function due to asphyxia are dependent from its severity. Severe intracellular acidosis due to the accumulation of lactic acid generated from the anaerobic metabolism of glucose provoke reducing ATP levels and Na-K-ATPase activity with intracellular accumulation of sodium and water and cell swelling, later interstitial edema and capillary compression. As a result we have poor kidney function and accumulation toxic microelements.

\section{Conclusion}

For newborns with impaired renal function were typical high level of $\mathrm{Al}, \mathrm{Cd}, \mathrm{Pb}$ in blood serum during early neonatal period in case of moderate asphyxia or predominantly during whole $1^{\text {st }}$ month of life in case of severe form. Prolonged increase levels of toxic elements in erythrocytes more specific for neonates with disturbance kidney function due to severe asphyxia. Transmembrane ratio of all investigated toxic elements indicated on preferred movement ions inward of the cell.

\section{References:}

1. Gupta B.D. Renal failure in asphyxiated neonates. / Gupta B.D., Sharma P., Bagla J ., et al. // Indian Pediatrics. 2005. Vol. 42. P. 928-934.

2. Shah P. Multiorgan dysfunction in infants with post-asphyxial hypoxic-ischaemic encephalopathy. / Shah P., Riphagen S., Beyene J., Perlman M. // Arch. Dis. Child. Fetal. Neonatal. 2004. Vol. 89. P 152-155.

3. J omova K. Advances in metal-induced oxidative stress and human disease. / J omova K., Valko M. // Toxicology. 2011. Vol. 283. P. 65-87.

4. J ärup L. Current status of cadmium as an environmental health problem. / J ärup L., Åkesson A. // Toxicol. Appl. Pharmacol. 2009. Vol. 238. P. 201-208.

5. Benett, R.W. Experimental studies on the effects of aluminum on pregnancy and fetal development. / Benett R.W., Persaud T.V.N., Moore K.L. // Anat. Anz. 1975. Vol. 138. P. 365-378.

6. Kulikova N.Yu. Kliniko-funktsional'naya kharakteristika ishemicheskoy nefropatii u donoshennykh novorozhdennykh, nakhodyashchikhsya $\mathrm{v}$ kriticheskom sostoyanii (mekhanizmy formirovaniya, prognozirovanie, rannyaya diagnostika, profilaktika, korrektsiya). Avtoreferat dis. ... dokt. med. nauk [Clinical and functional characteristics of ischemic nephropathy in full-term newborns being in critical condition (mechanisms of formation, prognostication, early diagnosis, prevention, correction). Dissertation for the degree of Doctor of medical science]. Ivanovo, 2011.

7. Taylor C.M. Lead, cadmium and mercury levels in pregnancy: the need for international consensus on levels of concern. / Taylor C.M., GoldingJ ., Emond A.M. // J . Dev. Orig. Health. Dis. 2014. Vol. 5, №1. P. 16-30.

8. Birgisdottir B.E. Essential and toxic element concentrations in blood and urine and their associations with diet: results from a Norwegian population study including high-consumers of seafood and game. / Birgisdottir B.E., Knutsen H.K., Haugen M., et al. // Sci. Total. Environ. 2013. Vol. 463-464. P. 836-844.

9. Sun $\mathrm{H}$. The effects of prenatal exposure to low-level cadmium, lead and selenium on birth outcomes. / Sun H., Chen W., Wang D., et al. // Chemosphere. 2014. Vol. 108. P. 33-39.

10. Savabieasfahani M. Toxic and essential trace metals in first baby haircuts and mother hair from Imam Hossein Hospital Tehran, Iran. / Savabieasfahani M., Hoseiny M., Goodarzi S. // Bull. Environ. Contam. Toxicol. 2012. Vol. 88, №2. P. 140-144.

11. Winiarska-Mieczan A. Cadmium, Lead, Copper and Zinc in Breast Milk in Poland. / Winiarska-Mieczan A. // Biol. Trace Elem. Res. 2014. Vol. 157. P. 36- 44.

12. Savolainen H. Cadmium-associated renal disease. / Savolainen H. // Ren. Fail. 1995. Vol. 17, №5. P. 483-487. 
13. Patriarca M. Environmental exposure to metals of newborns, infants and young children. / Patriarca M, Menditto A, Rossi B, et al. // Micro. J ournal. 2000. Vol. 67. P. 351-361.

14. Ni W. Associations of neonatal lead, cadmium, chromium and nickel co-exposure with DNA oxidative damage in an electronic waste recycling town. / Ni W., Huang Y., Wang X., Zhang J., Wu K. // Sci. Total. Environ. 2014. Vol. 472. P. 354-362.

15. Mladenović J. Protective effects of oestradiol against cadmium-induced changes in blood parameters and oxidative damage in rats. / Mladenović J., Ognjanović B., Dorđević N., et al. // Arh. Hig. Rada Toksikol. 2014. Vol. 65, №1. P. 37-46.

16. Manahan S.E. Toxicological chemistry and biochemistry / by S.E. Manahan. 3rd ed. USA: Lewis Publishers, 2003, 450 p.

17. Yokel R.A. Blood-brain barrier flux of aluminum, manganese, iron and other metals suspected to contribute to metal-induced neurodegeneration. / Yokel RA. // J. Alzheimers Dis. 2006. Vol. 10, №2-3. P. 223-253.

УДК 616.61-008.64- 053.2-001.8

\title{
Содержание токсических элементов в сыворотке крови и эритроцитах новорожденных детей с нарушением функции почек вследствие асфиксии
}

\author{
Андрей Николаевич Лобода
}

Сумский государственный университет, Украина

Кафедра педиатрии с курсом медицинской генетики

ул. Санаторная, 31, г. Сумы, Украина 40018

Кандидат медицинских наук, доцент

E-mail: fafik1313@rambler.ru

Аннотация. Цель исследования - изучить особенности содержания и баланса токсичных элементов (алюминий, кадмий и свинец) в сыворотке крови и эритроцитах новорожденных с нарушением функции почек вследствие асфиксии.

Обследовано 200 доношенных новорожденных с признаками повреждения почек: 100 новорожденных с тяжелой асфиксией и 100 детей, которые перенесли умеренную асфиксию. Группу сравнения составили 20 детей без асфиксии при рождении. Кровь забирали на 1-2 день жизни, в конце раннего неонатального периода (7-8 день жизни) и в конце первого месяца жизни (25-30 день). Содержание электролитов в сыворотке крови и эритроцитах определяли методом атомно-абсорбционной спектрофотометрии (AАC).

Для новорожденных с нарушением функции почек были характерны высокие уровни алюминия, кадмия, свинца в сыворотке крови в динамике раннего неонатального периода в случае умеренной асфиксии или преимущественно в течение всего 1-го месяца жизни в случае тяжелой асфиксии при рождении. Длительное повышение уровня токсичных микроэлементов в эритроцитах более характерно для новорожденных с нарушением функции почек вследствие тяжелой асфиксии. Трансмембранные соотношения всех исследованных токсичных элементов указывают на предпочтительное передвижение ионов внутрь клетки.

Ключевые слова: асфиксия, новорожденный, токсический микроэлемент, сыворотка, эритроцит. 